\title{
Assessment of Variation in Thermal Sensations Determined Based on Effective Temperature
}

\author{
Katarzyna Rymuza ${ }^{1 *}$, Elżbieta Radzka', Gracja Świerzycka' \\ 1 Faculty of Natural Sciences, Siedlce University of Natural Sciences and Humanities, ul. Prusa 14, 08-110 Siedlce, \\ Poland \\ * Corresponding author's e-mail: katarzyna.rymuza@uph.edu.pl
}

\begin{abstract}
Air temperature is one of major factors in a subjective assessment of human thermal comfort and discomfort. The work draws on a series of measurements of the average daily air temperatures, relative air humidity and wind speed for 2000-2016 recorded at the Siedlce Meteorological Station. The station is part of the state observation and measurement network of the hydrological and meteorological service of The Institute of Meteorology and Water Management - National Research Institute (IMGW-PIB). The effective temperature was calculated according to the formula recommended by Missenard and the thermal sensation was determined based on a scale suggested by Baranowska. The number of days with individual thermal sensations in individual months of the long-term period was calculated, and months were put into groups of similar sensations by means of principal component analysis (PCA) and cluster analysis. In the last years $(2015,2014,2012$ and 2011) in the months representing the cold season of the year, there were more days which were very cold and cold, whereas the number of days with the thermal comfort was much lower. The long-term period was split into three groups, based on the thermal comfort in the warm season of the year. The years which formed one group included 2011, 2013, 2015 and 2016 when there were no very cold days, the least cold days and the most very hot days.
\end{abstract}

Keywords: thermal sensations, effective temperature, human body

\section{INTRODUCTION AND WORK OBJECTIVE}

Specific bioclimatic conditions start to prevail as a result of the local factors in a given area, which are influenced by land topography, cover and use (Kossowska-Cezak et al. 2000, Szwejkowski 2002, Ustrnul and Czekierda 2002). As a result of the socio-economic progress and the development of many economy branches, the thermal balance of active surfaces is changing, which is particularly noticeable in large urban agglomerations, the so-called Urban Heat Islands. As a result of this process, there is an increase in the air temperature stimulativeness in both temporal and spatial terms (Olejniczak 2003, Fortuniak et al. 2006, Dudek et al. 2008, Czarnecka et al. 2011). The thermal exchange between the body surface and its environment depends on the air temperature, movement and humidity. Warmth loss increases in the environment characterised by low humidity (dry air), but declines when air humidity increases. At high air temperatures and humidity, water evaporation from the skin and airways is hindered, which results in breathlessness (Fleming 1983, Kożuchowski and Żmudzka 2001). The general concept of sensation appeared in the 1940s, mentioned by Paul Allman Siple and Charles Passe. When the weather is sunny and windless, the human thermal sensation increases, compared with rainy and windy weather. Bioclimatology applies a thermal sensation scale which was developed based on a thermal exchange balance and skin temperature value. The thermal exchange balance is a basic thermo-physiological indicator, which shows objective thermal sensations, rate and extent of warmth content change in the human body. The thermal sensations felt by a human being fall into a wide range, from severe hypothermia to overheating. The range in which a body feels comfortable substantially varies. Nor- 
mally, older persons and women feel better at higher temperatures, whereas men and young persons prefer lower temperatures (Błażejczyk 2004). The thermal comfort for a person wearing light clothes and performing slight physical activity lies within the temperature range of $21-22^{\circ} \mathrm{C}$, and relative humidity is $50 \%$. Kozłowska-Szczęsna et al. (1997) claims that the temperature range of $18-23^{\circ} \mathrm{C}$ represents thermally neutral conditions. The thermal conditions of the environment which enable a body to preserve its thermal balance are also called the thermal comfort. The most important task of the thermoregulatory system is to preserve the normal internal temperature. The efficiency of this system is supported by metabolism, appropriate clothes and sweating. Strengthening the thermoregulatory system is also of importance.

In Poland, the average annual air temperature is in the range from $6^{\circ} \mathrm{C}$ to $8.5^{\circ} \mathrm{C}$. The Sandomierz Basin and the Silesia Lowland are the warmest regions, whereas the mountainous areas, where the recorded temperatures drop as altitude increases $\left(0.8^{\circ} \mathrm{C}\right.$ per $\left.100 \mathrm{~m}\right)$, are the coldest (Błażejczyk 2004).

\section{MATERIALS AND METHODS}

The work draws on the data obtained from the Siedlce Meteorological Station for the years 2000-2016. The data included the average daily air temperatures, relative air humidity and wind speed. The effective temperature was calculated for the study period using the formulae by Missenard (as cited in Kozłowska-Szczęsna et al. 1997) The parameter reflects human thermal sensation of a fully-dressed or half-dressed (stripped to the waist) person staying in the shade. The following formulae are used to calculate the parameter in relation to the wind speed:

$$
\begin{aligned}
& \text { when } \mathrm{v} \leq 0.2 \mathrm{~m} \cdot \mathrm{s}^{-1} \\
& T E=t-0.4 \cdot(t-10,0) \cdot[1-0.01 \cdot f], \\
& \text { when } \mathrm{v}>0.2 \mathrm{~m} \cdot \mathrm{s}^{-1} \\
& T E=37.0-\frac{37-t}{0.68-0,0014 \cdot f+\frac{1,0}{1.76+1.40 \cdot v^{0.75}}}- \\
& -0.29 \cdot t \cdot[1-0.01 \cdot f],
\end{aligned}
$$

where: $t$ - air temperature,

$f$ - relative humidity in $\%$,

$v$ - wind speed in $\mathrm{m} \cdot \mathrm{s}^{-1}$.

The thermal sensation of the body was determined based on a seven-degree scale by Baranowska (Table 1). It describes the actual sensation and adaptation of the human body to various meteorological conditions.

The principal component analysis (PCA) was used to examine the variation in the thermal sensations in individual months of the long-term period (Mohammadi and Prasanna 2003; Di Giorgio et al. 2009; Upadhyaya et al. 2011). Only the principal components which, according to the Kaiser (1958) criterion, had the eigenvalues greater than 1 were chosen for analysis and interpretation. Next, in order to group the months with similar thermal sensations, the cluster analysis was performed using the Ward method, the Euclidean distance being chosen as a measure of multivariate dissimilarity of objects according to the formula (Casler and van Santen 2000; Mohammadi and Prasanna 2003; Crossa and Franco 2004):

\begin{tabular}{|c|c|c|c|c|c|c|c|}
\hline Month & Very cold & Cold & Cool & Comfortable & Warm & Hot & Very hot \\
\hline January & $<-18$ & -18 to -14 & -14 to -9 & -9 to -2 & & & \\
\hline February & $<-17$ & -17 to -11 & -11 to -6 & -6 to 0 & & & \\
\hline March & $<-13$ & -13 to- -7 & -7 to -2 & -2 to -4 & & & \\
\hline April & $<-7$ & -7 to -2 & -2 to -2 & 2 to 8 & 8 to 12 & 12 to 16 & $>16$ \\
\hline May & $<-2$ & -2 to -2 & 2 to 6 & 6 to 11 & 11 to 16 & 16 to 19 & $>19$ \\
\hline June & & $<6$ & 6 to 9 & 9 to 14 & 14 to 18 & 18 to 22 & $>22$ \\
\hline July & & $<8$ & 8 to 12 & 12 to 15 & 15 to 19 & 19 to 23 & $>23$ \\
\hline August & & $<8$ & 8 to 12 & 12 to 15 & 15 to 19 & 19 to 22 & $>22$ \\
\hline September & $<1$ & 1 to 5 & 5 to 9 & 9 to 13 & 13 to 17 & 17 to 21 & $>21$ \\
\hline October & $<-3$ & -3 to -1 & -1 to -5 & 5 to 10 & 10 to 15 & 15 to 19 & $>19$ \\
\hline November & $<-14$ & -14 to -8 & -8 to -2 & -2 to -4 & & & \\
\hline December & $<-17$ & -17 to -11 & -11 to -6 & -6 to -1 & & & \\
\hline
\end{tabular}

$$
\mathrm{d}\left(\mathrm{x}_{\mathrm{r}}, \mathrm{x}_{\mathrm{s}}\right)=\sqrt{\sum_{\mathrm{i}=1}^{\mathrm{p}}\left(\mathrm{x}_{\mathrm{ri}}-\mathrm{x}_{\mathrm{si}}\right)^{2}}
$$

Table 1. Assessment of the sensed climate based on effective temperature developed by Baranowska et al. (1986) in ${ }^{\circ} \mathrm{C}$ 
where: $x_{r}$ and $x_{s}$ are p-dimensional observation vectors of the $r$-th and $s$-th object $(\mathrm{r}, \mathrm{s}=1,2, \ldots, \mathrm{n})$.

Clusters were obtained by dividing the dendrogram using the Mojena's rule according to which the cut-off point is the bond distance for which the inequality described by the following formula holds:

$$
d_{i+1}>\bar{d}+k s_{d}
$$

where: $\overline{\mathrm{d}}$ - the mean,

$\mathrm{s}_{\mathrm{d}}$ - standard deviation,

$d_{i}$ - distance of the bond,

$k-$ a constant from the range 2.75 to 3.50

(Mojena 1977). Following Milligan and

Cooper (1985),

$k$ was assumed to equal 1.25 .

The groups of months formed by the cluster analysis were subjected to the analysis in the years 200-2016 by using PCA and cluster analysis again. The resultant information concerned the variation of years in terms of the thermal sensations in individual groups of months representing the cold and warm season of the year.

\section{RESULTS}

According to Cibor and Michalska (2007), optimum biothermal conditions occur when cool, comfortable and warm sensations are noted. In the long-term period (2000-2016), the number of cool days was the greatest in November and March, the days with comfortable weather in
January, February and December, and warm days in August, July and June. To some extent, the results correspond to the findings by Cibor and Michalska (2007) who reported that the most and least days with optimum biothermal conditions in north-eastern Poland occurred in autumn and summer, respectively.

In the studied period, on average, the greatest number of days with extreme sensations, that is 'very cold' and 'cold' was recorded in January, February and May, and 'hot' and 'very hot' from April to October (Table 2). Moreover, in 2000-2016, the most hot and very hot days occurred in May, and cold and very cold days - from November to February. These observations are in partial agreement with the reports by KossowskaCezak (2005) who claimed that an occurrence of cold and very cold days (from December to February) as well as hot and very hot days (from June to August) results in the greatest variation in the thermal sensations.

The principal component analysis demonstrated that the first 3 components, the eigenvalue of which was higher than 1 , accounted for almost $90 \%$ of the variation in thermal sensations in individual months. The first principal component, explaining $54.34 \%$ of total variance, was the most strongly correlated with the number of days described as warm (-0.954), hot (0.941), very hot (0.824) and cool (0.874), the sensations being most strongly affected by months. Reciprocal relationships show that in the months with many warm days, there were also numerous hot and very hot days but fewer cool days. The second principal component was strongly correlated with the average number of comfortable $(-0.762)$ and cold days (-0.760), affecting the thermal sensa-

Table 2. Structures of the average numbers of days (2000-2016) with individual thermal sensations in months

\begin{tabular}{|l|c|c|c|c|c|c|c|}
\hline \multirow{2}{*}{ Month } & \multicolumn{9}{c|}{ Thermal sensations } & Very hot \\
\cline { 2 - 9 } & Vey cold & Cold & Cool & Comfortable & Warm & Hot & V \\
\hline January & 10 & 10 & 25 & 55 & 0 & 0 & 0 \\
\hline February & 12 & 13 & 27 & 48 & 0 & 0 & 0 \\
\hline March & 0 & 17 & 68 & 15 & 0 & 0 & 11 \\
\hline April & 0 & 8 & 8 & 34 & 31 & 18 & 14 \\
\hline May & 14 & 0 & 5 & 19 & 42 & 21 & 6 \\
\hline June & 0 & 0 & 4 & 27 & 43 & 31 & 6 \\
\hline July & 0 & 0 & 5 & 15 & 45 & 21 & 9 \\
\hline August & 0 & 3 & 5 & 18 & 32 & 11 & 8 \\
\hline September & 0 & 3 & 13 & 33 & 37 & 26 & 4 \\
\hline October & 0 & 3 & 4 & 26 & 0 & 0 & 0 \\
\hline November & 0 & 25 & 75 & 0 & 0 & 0 & 0 \\
\hline December & 0 & 31 & 25 & 44 & & & 0 \\
\hline
\end{tabular}


tions in individual months in $20 \%$. In the months when there were more days with comfortable weather, there were also more very cold days. The third component accounted for only $15.51 \%$ variation, and was associated with the number of comfortable and cold days (Table 3).

The cluster analysis yielded two groups of months with different sensations. The first group included January, February, March, November and December. The second group was formed by the remaining months. On average, the months in the first group had more cold days, whereas the second group consisted of the months with a greater number of warm days. Thus, the first group was called a cold season, while the second group a warm season of the year (Fig. 1, Table 4).

In the long-term period, the 'very cold' sensation was recorded only five times. The most days of this type were found in 2006, 2012 and 2010. The most cold days were recorded in 2002 , 2012, 2009, 2011 and 2014. The greatest number of cool days was found in 2010. Due to the cold season of the year, no warm, hot or very hot sensations were recorded. The least days described as comfortable were observed in 2014, 2015 and 2008 (Table 5). Similar findings were reported by Kossowska-Cezak (2005) based on the measurements taken at the Warszawa Okęcie Station. The

Table 3. Eigenvalues, proportion of the first three principal components in the total variation, and coefficients of correlation between the components and thermal sensations

\begin{tabular}{|l|c|c|c|}
\hline \multirow{2}{*}{\multicolumn{1}{|c|}{ Trait }} & \multicolumn{3}{c|}{ Principal component } \\
\cline { 2 - 4 } & PC1 & PC2 & PC3 \\
\hline Very cold & -0.143 & -0.760 & -0.601 \\
\hline Cold & 0.734 & -0.271 & 0.447 \\
\hline Cool & 0.874 & -0.198 & -0.138 \\
\hline Comfortable & -0.086 & -0.762 & 0.579 \\
\hline Warm & -0.954 & 0.031 & 0.249 \\
\hline Hot & -0.941 & 0.104 & 0.132 \\
\hline Very hot & -0.824 & -0.395 & -0.143 \\
\hline Eigenvalue & 3.80 & 1.44 & 1.02 \\
\hline Proportion of variation explained (\%) & 54.34 & 20.56 & 14.51 \\
\hline Cumulated proportion of variation explained (\%) & 54.34 & 74.90 & 89.40 \\
\hline
\end{tabular}

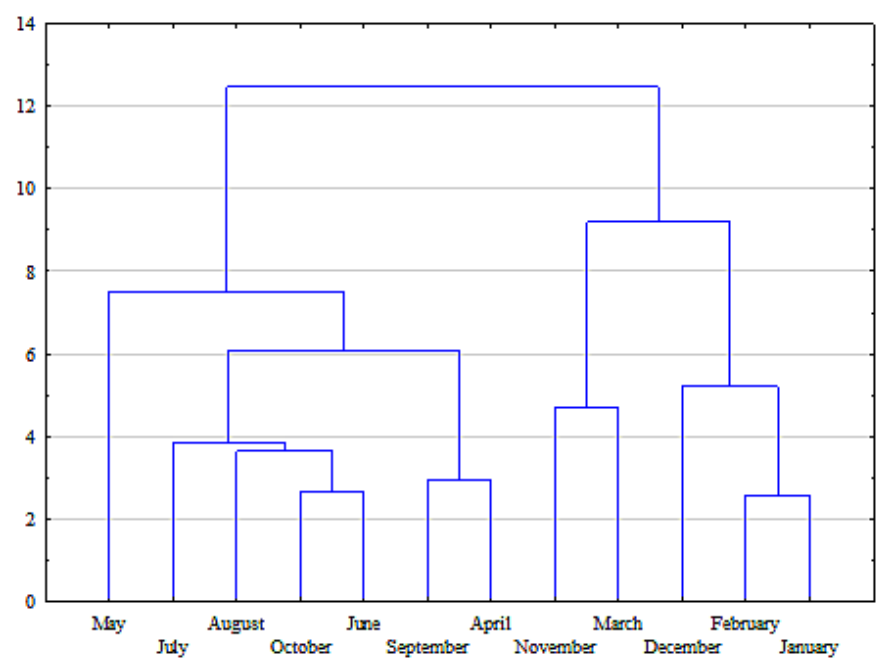

Fig. 1. Dendrogram of grouping of months in terms of the thermal sensations for the years 2000-2016

Table 4. Average values of the thermal sensations for two groups of months formed based on the cluster analysis

\begin{tabular}{|c|c|c|c|c|c|c|c|}
\hline Groups & Very cold & Cold & Cool & Comfortable & Warm & Hot & Very hot \\
\hline Group 1 & 1.0 & 2.9 & 5.4 & 6.7 & 0.0 & 0.0 & 0.0 \\
\hline Group 2 & 0.9 & 0.9 & 2.2 & 8.8 & 13.2 & 7.1 & 3.0 \\
\hline
\end{tabular}


Table 5. Structure of the number of days with individual types of sensations in the cold season of the year (the first group) in 2000-2016

\begin{tabular}{|c|c|c|c|c|c|c|c|}
\hline Years & Very cold & Cold & Cool & Comfortable & Warm & Hot & Very hot \\
\hline 2000 & 0.0 & 0.0 & 3.4 & 6.8 & 0.0 & 0.0 & 0.0 \\
\hline 2001 & 0.0 & 6.5 & 5.9 & 8.4 & 0.0 & 0.0 & 0.0 \\
\hline 2002 & 9.1 & 15.6 & 5.0 & 4.8 & 0.0 & 0.0 & 0.0 \\
\hline 2003 & 9.1 & 3.9 & 8.4 & 5.9 & 0.0 & 0.0 & 0.0 \\
\hline 2004 & 0.0 & 1.3 & 8.1 & 8.4 & 0.0 & 0.0 & 0.0 \\
\hline 2005 & 0.0 & 7.8 & 6.2 & 9.0 & 0.0 & 0.0 & 0.0 \\
\hline 2006 & 36.4 & 3.9 & 9.9 & 7.1 & 0.0 & 0.0 & 0.0 \\
\hline 2007 & 0.0 & 3.9 & 5.0 & 6.9 & 0.0 & 0.0 & 0.0 \\
\hline 2008 & 0.0 & 0.0 & 3.7 & 3.1 & 0.0 & 0.0 & 0.0 \\
\hline 2009 & 0.0 & 10.4 & 4.7 & 6.9 & 0.0 & 0.0 & 0.0 \\
\hline 2010 & 18.2 & 3.9 & 10.6 & 5.1 & 0.0 & 0.0 & 0.0 \\
\hline 2011 & 0.0 & 10.4 & 4.7 & 4.4 & 0.0 & 0.0 & 0.0 \\
\hline 2012 & 27.3 & 15.6 & 6.2 & 4.8 & 0.0 & 0.0 & 0.0 \\
\hline 2013 & 0.0 & 3.9 & 7.5 & 8.2 & 0.0 & 0.0 & 0.0 \\
\hline 2014 & 0.0 & 10.4 & 8.1 & 2.2 & 0.0 & 0.0 & 0.0 \\
\hline 2015 & 0.0 & 0.0 & 0.9 & 1.5 & 0.0 & 0.0 & 0.0 \\
\hline 2016 & 0.0 & 2.6 & 1.9 & 6.6 & 0.0 & 0.0 & 0.0 \\
\hline
\end{tabular}

author found that cold days were noted 204 times per one year, on average, mainly from August to mid-March, and the greatest number of cold occurred from November to March.

The principal component analysis revealed that the years 2000-2016 were affected by the number of days with individual types of thermal sensations in 74\%. The variation was associated with the first two principal components. The first component explained $42 \%$ of the variation associated mainly with the 'cool' and 'very cold' sensations. The 'cold' and 'comfortable' sensations were affected by the analysed period in $30 \%$. Reciprocal associations indicate that in the years with more cold days there were also more very cold days. Moreover, in the years with more comfortable days, there were fewer cold days (Table 6).

The cluster analysis yielded two groups of years in the cold season of the year. The first group consisted of 2002, 2012, 2014, 2008 and 2015, the second group included the remaining years (Fig. 2).

The years in the first group were characterised by a greater average number of very cold and cold days. Thus, it is noticeable that in the last years (2015, 2014, 2012 and 2011), there were more days which were very cold and cold, whereas the number of comfortable days declined, on average (Table 7).

In the warm season of the year, in the months which were selected in the cluster analysis, the 'very cold' sensation was recorded only in 2012 and 2005. The 'cold' sensation was not present in the last year. The greatest number of cold days in the long-term period was found in 2003, 2007 and 2000. From 2007 to 2016, the number of cold days did not exceed $5 \%$ but there was an increase in the percentage of hot and very hot days (Table 8).

Multivariate principal component analysis demonstrated that the variation between years in the warm season of the year was explained by the thermal sensations in $77.2 \%$. Almost $40 \%$ variation was affected by the sensations associated with the first principal component, that is 'very hot' ( $\mathrm{r}=-0.809)$, 'hot' $(-0.757)$ and 'comfortable' $(0.733)$. The second principal component ac-

Table. 6. Eigenvalues, proportion of the first two principal components in the total variation and coefficients of correlation between the components and thermal sensations in the cold season of the year

\begin{tabular}{|l|c|c|}
\hline \multirow{2}{*}{\multicolumn{1}{|c|}{ Trait }} & \multicolumn{2}{c|}{$\begin{array}{c}\text { Principal } \\
\text { component }\end{array}$} \\
\cline { 2 - 3 } & PC1 & PC2 \\
\hline Very cold & 0.831 & -0.205 \\
\hline Cold & 0.442 & -0.600 \\
\hline Cool & 0.855 & 0.256 \\
\hline Comfortable & 0.260 & 0.834 \\
\hline Eigenvalue & 1.680 & 1.160 \\
\hline Proportion of variation explained (\%) & 42.10 & 29.07 \\
\hline $\begin{array}{l}\text { Cumulated proportion of variation } \\
\text { explained (\%) }\end{array}$ & 42.10 & 71.17 \\
\hline
\end{tabular}




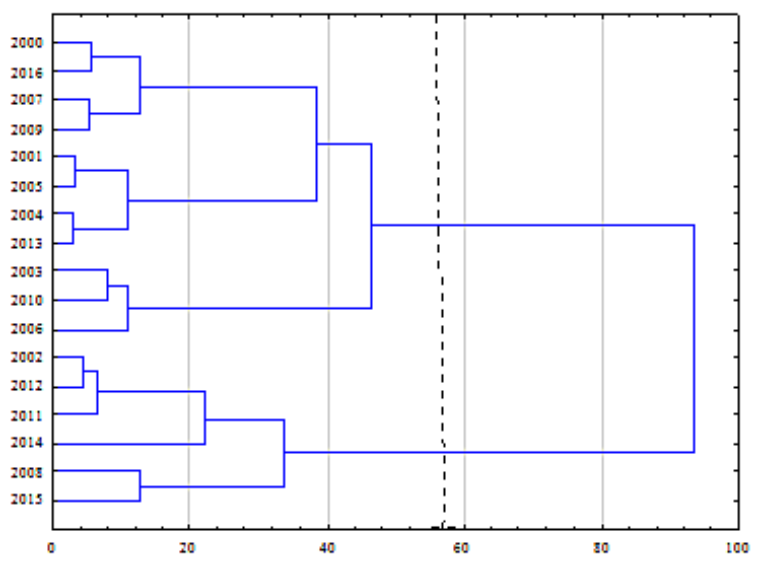

Fig. 2. Dendrogram of grouping of years in terms of the thermal sensations in the cold season of the year

Table 7. Average values of the thermal sensations in the cold season of the year for two groups of years formed in the cluster analysis

\begin{tabular}{|c|c|c|c|c|}
\hline Groups & Very cold & Cold & Cool & Comfortable \\
\hline Group 1 & 0.8 & 6.4 & 15.4 & 17.8 \\
\hline Group 2 & 0.6 & 3.8 & 20.4 & 38.2 \\
\hline
\end{tabular}

counted for nearly $20 \%$ variation between traits, and was principally associated with the sensation 'warm' ( $\mathrm{r}=0.720)$ and 'comfortable' $(-0.557)$. The third component was connected with the 'cold' $(\mathrm{r}=0.719)$ and 'cool' sensations (0.630) (Table 9).

The cluster analysis yielded three groups of years characterised by different thermal sensations in the warm season of the year. The first group consisted of 2001, 2002, 2012 and 2014, which had the greatest average number of very cold, cool and warm days. The second group included the 'last' years, that is 2011, 2013, 2015 and 2016 with no very cold days, the lowest number of cold days and the greatest number of very hot days. The third group was made up of the years which, in the long-term period, had the highest average number of cold, comfortable and warm days, and the lowest number of hot and very hot days (Fig. 3, Table 10).

\section{CONCLUSIONS}

1. In the period 2000-2016, the most days with optimum biothermal conditions were recorded in November and March ('cool' sensation), January, February and December ('comfortable' sensation), and August, July and June ('warm' sensation).

2. The numbers of warm, cool, hot and very hot days were influenced the most by the months in the period 2000-2016. The cluster analysis yielded two groups of months characterised by different thermal sensations. The first group included January, February, March, November and December. The second group consisted of the remaining months. The first group was called the cold season of the year and the second group the warm season of the year.

3. In the long-term season, the 'very cold' sensation was recorded only five times in the cold season of the year. In the last years $(2015,2014$,

Table 8. Structure of days with individual types of thermal sensations in the warm season of the year (the second group) in 2000-2016

\begin{tabular}{|c|c|c|c|c|c|c|c|}
\hline Years & Very cold & Cold & Cool & Comfortable & Warm & Hot & Very hot \\
\hline 2000 & 0.0 & 12.2 & 6.8 & 5.7 & 5.5 & 6.0 & 6.8 \\
\hline 2001 & 0.0 & 9.8 & 5.5 & 5.3 & 6.8 & 7.3 & 0.0 \\
\hline 2002 & 0.0 & 2.4 & 6.0 & 5.0 & 6.9 & 8.0 & 1.4 \\
\hline 2003 & 0.0 & 14.6 & 7.5 & 5.7 & 6.1 & 2.7 & 4.1 \\
\hline 2004 & 0.0 & 7.3 & 6.8 & 6.5 & 5.2 & 5.0 & 0.0 \\
\hline 2005 & 12.5 & 2.4 & 6.9 & 6.2 & 5.9 & 3.0 & 4.1 \\
\hline 2006 & 0.0 & 9.8 & 4.6 & 6.5 & 6.9 & 2.3 & 0.0 \\
\hline 2007 & 0.0 & 12.2 & 5.0 & 6.9 & 4.9 & 4.3 & 10.8 \\
\hline 2008 & 0.0 & 2.4 & 5.0 & 7.5 & 5.7 & 2.3 & 0.0 \\
\hline 2009 & 0.0 & 2.4 & 4.4 & 6.3 & 7.2 & 3.7 & 0.0 \\
\hline 2010 & 0.0 & 2.4 & 5.9 & 6.0 & 6.4 & 5.3 & 0.0 \\
\hline 2011 & 0.0 & 4.9 & 4.8 & 5.9 & 5.9 & 6.3 & 12.2 \\
\hline 2012 & 87.5 & 4.9 & 6.9 & 4.7 & 5.1 & 7.7 & 17.6 \\
\hline 2013 & 0.0 & 4.9 & 5.3 & 6.0 & 5.1 & 7.3 & 14.9 \\
\hline 2014 & 0.0 & 4.9 & 6.9 & 4.2 & 6.2 & 10.0 & 10.8 \\
\hline 2015 & 0.0 & 2.4 & 5.3 & 6.1 & 5.3 & 8.7 & 6.8 \\
\hline 2016 & 0.0 & 0.0 & 6.2 & 5.6 & 4.9 & 10.0 & 10.8 \\
\hline
\end{tabular}


Table. 9. Eigenvalues, proportion of the first three principal components in the total variation and coefficients of correlation between the components and the thermal sensations in the warm season of the year

\begin{tabular}{|l|c|c|c|}
\hline \multirow{2}{*}{\multicolumn{1}{|c|}{ Trait }} & \multicolumn{3}{c|}{ Principal component } \\
\cline { 2 - 4 } & PC1 & PC2 & PC3 \\
\hline Very cold & -0.622 & -0.201 & 0.101 \\
\hline Cold & 0.156 & -0.451 & 0.719 \\
\hline Cool & -0.565 & -0.043 & 0.630 \\
\hline Comfortable & 0.733 & -0.557 & -0.349 \\
\hline Warm & 0.524 & 0.720 & 0.294 \\
\hline Hot & -0.757 & 0.421 & -0.277 \\
\hline Very hot & -0.809 & -0.336 & -0.246 \\
\hline Eigenvalue & 2.77 & 1.36 & 1.30 \\
\hline Proportion of variation explained (\%) & 39.57 & 19.49 & 18.13 \\
\hline Cumulated proportion of variation explained (\%) & 39.57 & 59.06 & 77.20 \\
\hline
\end{tabular}

2012 and 2011), there were more very cold and cold days, whereas the number of comfortable days was much lower.

4. In the warm season of the year, the number of cold days remained at a similar level from 2007 to 2016, whereas the number of hot and very hot was on the increase.

5. The cluster analysis yielded three groups of years with different thermal sensations in the warm seasons of the year. There were no very cold days in the group consisting of the last years $(2011,2013,2015$ and 2016), the number of very cold days being the lowest and the number of very hot days being the highest.

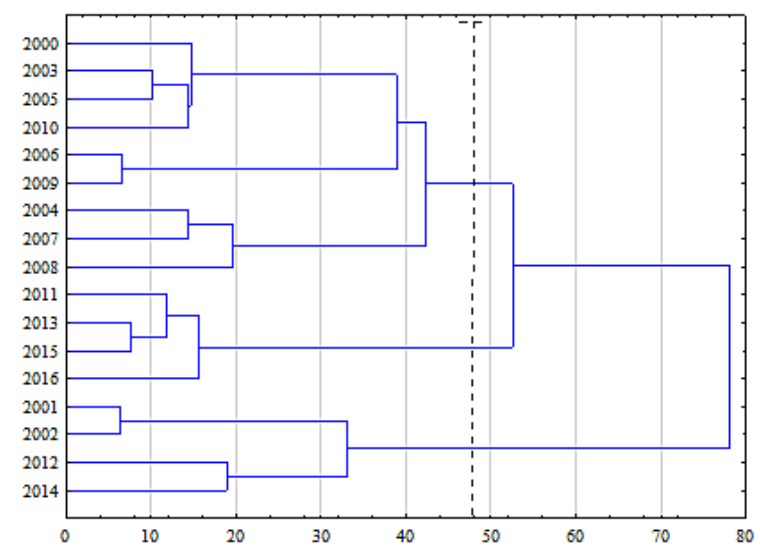

Fig. 3. Dendrogram of grouping of years in terms of the thermal sensations in the warm season of the year

\section{REFERENCES}

1. Baranowska M., Boniecka-Żółcik H., Gurba A., 1986. Weryfikacja skali klimatu odczuwalnego dla Polski, Przegląd Geofizyczny, 31, 1, 27-40.

2. Błażejczyk K., 2004. Bioklimatyczne uwarunkowania rekreacji i turystyki w Polsce, IGiPZ PAN, Warszawa.

3. Casler M.D., van Santen E., 2000. Patterns of variation in a collection of meadow fescue accessions. Crop Sci. 40: 248- 255.

4. Chabior M., Michalska B., 2007. Ocena klimatu odczuwalnego w Polsce północno-wschodniej na podstawie temperatury radiacyjno-efektywnej (TRE), Acta Agrophysica, 10 (1), 19-29.

5. Crossa J., Franco J., 2004. Statistical methods for classifying genotypes. Euphytica 153, 19-37.

6. Czarnecka M., Mąkosza A., Nidzgorska-Lencewicz J., 2011, Variability of meteorological elements shaping biometeorological conditions in Szczecin, Poland. Theor. Appl. Climatol., 104, 1-2, 101-110.

7. Di Giorgio G., Graziano D., Ruisi P., Amato G., Giambalvo D., 2009. Pheno-morphological and agronomic diversity among Scorpiurus muricatus (Fabaceae) natural populations collected in Sicily. J. Agric. Sci., 147, 411-422.

8. Dudek S., Kuśmierek R., Żarski J., 2008, Porównanie wybranych elementów meteorologicznych w Bydgoszczy i jej okolicy. Przegląd Naukowy Inżynieria i Kształtowanie Środowiska, 17, 1 (39), 35-41.

Table 10. Average values of the thermal sensations in the warm season of the year for three groups of years formed in the cluster analysis

\begin{tabular}{|c|c|c|c|c|c|c|c|}
\hline Groups & Very cold & Cold & Cool & Comfortable & Warm & Hot & Very hot \\
\hline Group 1 & 1.8 & 2.3 & 35.8 & 73.0 & 71.0 & 24.8 & 5.5 \\
\hline Group 2 & 0.0 & 1.3 & 30.5 & 89.5 & 60.3 & 24.3 & 8.3 \\
\hline Group 3 & 0.1 & 3.0 & 33.0 & 96.2 & 68.0 & 11.6 & 2.1 \\
\hline
\end{tabular}


9. Fleming G., 1983. Klimat-środowisko-człowiek, PWRiL, Warszawa.

10. Fortuniak K., Kłysik K., Wibig J., 2006, Urban-rural contrasts of meteorological parameters in Łódź. Theor. Appl. Climatol. 84, 91-101.

11. Kossowska-Cezak U., 2005. Warunki odczucia cieplnego określone na podstawie temperatury średniej dobowej (na przykładzie Warszawy). Balneologia Polska, 47, 1-2, 49-55.

12. Kossowska-Cezak U., Martyn D., Olszewski D., Kopacz-Lembowicz M., 2000. Meteorologia i klimatologia. Pomiary, obserwacje, opracowania. Wydawnictwo Naukowe PWN, Warszawa-Łodź.

13. Kozłowska- Szczęsna T., Błażejczyk K., Krawczyk B., 1997. Bioklimatologia człowieka. Metody i ich zastosowanie w badaniach bioklimatu Polski. IGiPZ PAN, Warszawa.

14. Kożuchowski K., Żmudzka E. 2001. Ocieplenie w Polsce. Skala i rozkład sezonowy zmian temperatury powietrza w drugiej połowie XX wieku. Przegląd Geofizyczny. z 1-2, 81-90.

15. Milligan G.W., Cooper M., 1985. An examination of procedures for determining the number of clusters in a data set. Psychometrica, 50(2), 159-179.
16. Mohammadi S.A., Prasanna B.M., 2003. Analysis of genetic diversity in crop plants - Salient statistical tools and considerations. Crop Science, 43, 1235-1248.

17. Mojena R., 1977. Hierarchical grouping methods and stopping rule: an evaluation. The Computer J., 20, 359-363.

18. Olejniczak J., 2003, The day-to-day variability of air temperature in Cracow and its surroundings. Prace Geogr., 112, IGiGP UJ, Kraków, 93-103.

19. Szwejkowski Z., 2002. Klimat pojezierza mazurskiego. Cz. II. Tendencje zmian podstawowych elementów meteorologicznych w regionie. Fragmenta Agronomica UWM, (19), 2(74).

20. Upadhyaya H.D., Ortiz R., Bramel P.J., Singh S., 2003. Development of a groundnut core collection using taxonomical, geographical and morphological descriptors. Gen. Res. Crop Evolution, 50,139-148.

21. Ustrnul Z., Czekierda D., 2002. Ekstremalne wartości temperatury powietrza w Polsce w drugiej połowie XX wieku na tle warunków cyrkulacyjnych. Wiadomości IMGW, XXVI (XLVI), 4, 3-8. 